\title{
VYUŽITIE ARCGIS DASHBOARDS NA ZOBRAZENIE DÁT O PANDÉMIÍ COVID-19
}

\author{
USE OF ARCGIS DASHBOARDS TO VISUALIZE COVID-19 PANDEMIC \\ DATA
}

Adriana Brezničanová

breznadr@fsv.cvut.cz

České vysoké učení technické v Praze, Fakulta stavební, Thákurova 7/2077, 16629 Praha 6 - Dejvice

\begin{abstract}
Abstrakt
Príspevok sa zaoberá aplikáciou ArcGIS Dashboards a jeho využitím na zobrazenie dát pandémie Covid-19. Predmetom je vyskúšanie funkcionality aplikácie a tiež jej aktualizácie v závislosti na meniacich sa dátach. Príspevok popisuje celý proces tvorby aplikácie od vytvorenia mapových vrstiev v programe ArcGIS Pro, cez spracovanie dát, ich publikáciu do prostredia ArcGIS Online, tvorbu dashboardu a jeho aktualizáciu. Výsledkom je priblíženie tvorby ArcGIS Dashboards a informovanie o priebehu pandémie na vytvorenom dashboarde. Vo výslednom dashboarde je zobrazená aktuálna situácia v okresoch a krajoch, informácie o očkovaní, obsadenosti nemocníc a tiež historické dáta.
\end{abstract}

\section{Kl’účové slová}

ArcGIS Dashboards, ArcGIS Online, dáta v reálnom čase, grafy, pandémia Covid-19

\begin{abstract}
The report deals with the ArcGIS Dashboards application and its use in displaying Covid-19 pandemic data. The subject is a description of the functionality of the application and also its updating depending on the changing data. The paper describes the entire process of creating an application, from creating map layers in ArcGIS Pro, through data processing, publishing them to ArcGIS Online, creating a dashboard and updating it. The result is an approach to the creation of ArcGIS Dashboards and informing about the course of the pandemic on the created dashboard. The resulting dashboard shows the current situation in districts and regions, information on vaccinations, hospital occupancy and also historical data.
\end{abstract}

Key words

ArcGIS Dashboards, ArcGIS Online, real-time data, charts, Covid-19 pandemic

\section{1 ÚVOD}

Ciel’om práce bolo preskúmat' použitie a možnosti aplikácie ArcGIS Dashboards v spojení s aktuálnou situáciou pandémie Covid-19. Snahou bolo popísat' čo najširšie spektrum možností použitia aplikácie ArcGIS Dashboards a približit' ju tak aj používatel'om u nás na dátach zobrazujúcich pandémiu Covid-19.

Prvý článok o uvedení aplikácie Operations Dashboards pre ArcGIS bol publikovaný v apríli 2013. Od začiatku pandémie Covid-19 v marci 2020 bola aplikácia viac a viac využívaná, pretože zobrazovala jej vývoj. Možno v ňom sledovat', ako za pomocí dát v reálnom čase postupuje pandémia do celého sveta. Spojenie mapy, grafov, štatistických dát a indikátorov pomáha l’ahkému porozumeniu situácie. Počas pandémie pomaly pribúdali rôzne spracovania dashboardov a každý z nich bol unikátny.

Dashboardy nám majú podávat' informácie o udalostiach, aby boli intuitívne a l'ahko pochopitel'né l'ud'mi v rámci organizácie, ale aj mimo nej. Vd’aka nim by malo byt' jednoduchšie rozhodovat' sa pri riadení určitých situácií, l'ahko získat' prehl'ad o situácií len za pomoci mapy, grafov, zoznamov a indikátorov. Vd'aka možnosti filtrovania je to všetko ešte jednoduchšie. Filter nám všetky informácie zobrazí v okne monitoru behom sekundy a my sme schopní hned' vidiet' informácie. Okrem zobrazenia v počítačovom prostredí možno informácie sledovat' aj na tabletoch, mobilných telefónoch, zdiel'at' ich s d'alšími l'ud'mi vo svete alebo vo svojej organizácií. Tiež ich možno vkladat' na vlastné webové stránky. 


\section{LITERÁRNY PREHLAD/POPIS SÚČASNÉHO STAVU}

\section{Známe Covid-19 ArcGIS Dashboards}

Slovensko má vytvorený jednoduchý Covid-19 Dashboard. Nachádza sa v ňom počet pozitívnych za posledných 21 dní, mapové okno so zobrazením Covid automatu (systém podobný systému PES v Českej republike) a graf zobrazujúci nové prípady za jednotlivé dni od 17. 8. 2020 [1].

Po prekliknutí na panel Zahraničie je už dashboard o niečo zaujímavejší. Tento panel sa odkazuje na Covid-19 Dashboard vytvorený Johns Hopkins University. Sú v ňom zobrazené základné informácie o vývoji pandémie pre celý svet [2].

\section{O aplikácií}

Dashboard je informačný panel alebo akási nástenka, ktorá umožňuje sledovat' udalosti, rozhodovat' sa, informovat' ostatných a sledovat' trendy. Dashboardy sú navrhnuté tak, aby zobrazovali viac možností vizualizácie, ktoré sú vzájomne prepojené. Ponúkajú komplexný prehl'ad o zobrazovaných údajoch a poskytujú klúčcvé informácie pre okamžité rozhodovanie [3].

Základnými vlastnost’ami dashboardov je teda l'ahká pochopitel'nost', vd’aka aplikácií l'ahká tvorba, interaktivita, flexibilita a mnoho možností konfigurácie. Vd’aka tomu, že sú ArcGIS Dashboards založené na webovom prehliadači, pracujú ako na desktopoch, tak aj na tabletoch či smartfónoch.

Dashboardy sú zložené z rôznych prvkov, ktoré možno l'ahko konfigurovat'. Sú to napríklad mapy, zoznamy, meradlá, indikátory a tieto prvky zaberajú $100 \%$ okna dashboardu. Tieto prvky možno spolu zoskupovat' alebo vkladat' do tabov. Dashboardy tiež ponúkajú možnost' filtrovania dát, pomocou ktorého si užívatel' môže zobrazit' záujmovú oblast' alebo informáciu. Taktiež ponúkajú funkciu posuvníkov, ktoré umožňujú pri dátach filtrovat' $\mathrm{v}$ čase.

Typy dashboardov môžu byt' rôzne - strategický, taktický/analytický, operačný alebo informačný. Strategické dashboardy slúžia riadiacim a vedúcim pracovníkom sledovat' kl’účové indikátory výkonu svojej organizácie a vykonávat' strategické rozhodnutia. Taktické alebo analytické pomáhajú analytikom analyzovat' zobrazované dáta a vizualizovat' ich tak, aby dátam lepšie porozumeli. Operačné alebo funkčné dashboardy využivajú zamestnanci operatívy na zobrazovanie dát v reálnom čase a porozumenie zobrazovaným dátam. Informačný je menej formálny a tvorcovia nim oslovujú alebo predávajú informácie užívatel’om z rôznych odvetví [4].

\section{Popis dát Covid-19}

Všetky dáta boli čerpané zo stránok Ministerstva zdravotníctva [5]. V sekcii Datové sady COVID-19 sa nachádza pät' kategórií dát - epidemiologické charakteristiky, testovanie, očkovanie, kapacity intenzívnej starostlivosti a rôzne.

Z kategórie Epidemiologické charakteristiky sú čerpané tri dátové sady. Dátová sada Základní přehled poskytuje stručný prehl'ad o vývoji pandemickej situácie. Obsahuje aktuálny počet vykonaných PCR a antigénnych testov, potvrdené prípady celkom a vo vekovej kategórií nad 65 rokov, aktívne prípady, počet vyliečených, počet úmrtí, počet očkovaní a počet hospitalizácií. Dátová sada Přehled epidemiologické situace dle hlášení krajských hygienických stanic podle okresu obsahuje kumulatívne hodnoty z predošlého dňa o počtoch osôb s preukázanou nákazou ochorením COVID-19, o počte vyliečených pacientov po ochorení COVID-19 a počet úmrtí v súvislosti s ochorením COVID-19. Dátová sada Protiepidemický systém ČR (PES) ponúka tri formáty dát - dáta pre celú republiku, dáta na úrovni krajov a dáta na úrovni okresov. Pre prácu bola použitá dátová sada na krajskej úrovni, ktorá obsahuje informácie o 14dennom počte novo nakazených na 100000 obyvatel'ov, 14dennom počte novo nakazených na 100000 obyvatel'ov vo veku nad 65 rokov, zjednodušený výpočet reprodukčného čísla a priemernú pozitivitu testov za posledných sedem dní (v súčasnosti už dátová sada Protiepidemický systém ČR PES nie je aktualizovaná).

Z kategórie Očkování je čerpaná dátová sada Přehled vykázaných očkování podle krajů ČR poskytuje agregované dáta o vykonaných očkovaniach na krajskej úrovni. Súbor obsahuje informácie o použitej vakcíne, počte podaných prvých dávok, počte podaných druhých dávok a dávok podaných celkom.

Z kategórie Kapacity intenzívnej starostlivosti je čerpaná dátová sada Online dispečink intenzivní péče - volné kapacity podle zdravotnických zařízení poskytuje dáta na úrovni krajov a obsahuje denné prehl'ady vol’ných kapacít v nemocniciach a tiež celkový počet lôžok. Obsahuje prehl'ad o štandardných lôžkach s kyslíkom, lôžkach HFNO (vysokoprietoková aplikácia kyslíku) / CPAP (trvalý pozitívny pretlak v dýchacích cestách), lôžkach UPV (umelá pl'úcna ventilácia) / NIV (neinvazívna ventilácia), lôžkach s kyslíkom na infekčnom oddelení, lôžkach s možnost'ou HFNO na infekčnom oddelení, lôžkach s možnost'ou UPV na infekčnom oddelení, prístrojoch 
ECMO (mimotelová podpora života) a CVVHD (kontinuálna venovenózna hemodyalýza), prenosných ventilátoroch a anesteziologických prístrojoch s ventilátorom.

\section{METODIKA}

\section{Príprava mapových vrstiev}

Príprava podkladových vrstiev krajov a okresov prebiehala v programe ArcGIS Pro. Vrstva krajov a okresov bola použitá z Digitálnej vektorovej geografickej databáze Českej republiky ArcČR 500 ver. 3.3. [6] Vrstvy boli transformované do zobrazenia Web Mercator. Obom vrstvám bola nastavená symbológia a transformované vrstvy boli vyexportované do ArcGIS Online. Symbológia, ktorá bola obom vrstvám nastavená v ArcGIS Pro sa však pri zdiel’aní vrstiev na ArcGIS Online nezachovala. Ďalej bola vytvorená podkladová mapa pomocou ArcGIS Vector Tile Style Editor [7].

\section{Príprava dát}

Dáta sú denne aktualizované pomocou piatich Python skriptov. Celkovo bolo vytvorených desat' skriptov, pre každú dátovú sadu dva. Prvý skript zabezpečil stiahnutie dát z MZČR, prípadne pripojenie d'alších stlípcov a ich výpočet a zdiel'anie na ArcGIS Online. Druhý skript je vel'mi podobný tomu prvému, ale ten zabezpečuje dennú aktualizáciu dát. Dáta sú aktualizované na základe jedinečného identifikátora, ktorý je generovaný v každom skripte a tiež je táto jedinečnost' atribútu nastavená v každej tabul'ke na ArcGIS Online. To, aby sa aktualizačné skripty spúšt’ali denne, bolo zabezpečené BAT súborom, ktorý bol v Task Manageri nastavený ako úloha spúšt’ajúca sa každý deň.

\section{Práca v ArcGIS Online}

Pre budúci dashboard boli vytvorené štyri webové mapy - webová mapa pozitívnych prípadov Covid-19 Dashboard pozitívni, webová mapa vyliečených pacientov Covid-19 Dashboard vyliečení, webová mapa úmrtí Covid-19 Dashboard úmrtia a webová mapa protiepidemického systému Covid-19 Dashboard PES. Tvorba bola pre všetky štyri webové mapy rovnaká. Rozdiel je len v popisoch jednotlivých krajov a okresov. V každej webovej mape sú pripojené vrstvy vzniknuté publikovaním dát do ArcGIS Online pomocou Python skriptov a pripojené na geometriu, a podkladová vrstva vytvorená v ArcGIS Vector Tile Style Editor. [7] Vrstva krajov zobrazuje agregované informácie tej istej tabul'ky, ako vrstva okresov. Obom vrstvám bola nastavená symbológia, nastavený rozsah vykresl'ovania vrstiev, upravené vyskakovacie a vytvorené popisy. Ked’že bolo ciel'om v dashboarde zobrazovat' aj históriu PES, muselo byt' pre webovú mapu Covid-19 Dashboard PES povolené nastavenie času. Vo webovej mape sa v spodnej časti objavil časový posuvník, v ktorého nastaveniach bol nastavený rozsah dátumov vykresl'ovania a to, že sa dáta budú vykresl'ovat' po dňoch. Toto nastavenie umožnilo v dashboarde nastavit' akcie na vol'bu dátumu v historických dátach PES.

\section{Tvorba dashboardu}

Ako prvý prvok bola vybraná mapa. Do dashboardu boli vložené štyri pripravené webové mapy - Covid-19 Dashboard pozitívni, Covid-19 Dashboard vyliečení, Covid-19 Dashboard úmrtia a Covid-19 Dashboard PES. V konfigurácií mapového prvku bolo povolené zobrazovanie pop-upov a pre mapový prvok zobrazujúci protiepidemický systém PES aj legenda a viditel'nost' vrstiev. Legenda protiepidemického systému PES zobrazuje index rizika. Vol'ba viditel'nosti vrstvy slúži na prepínanie medzi aktuálnymi a historickými dátami.

Ďalšími pridanými prvkami boli indikátory - počet nakazených, vyliečení, počet úmrtí, aktuálne hospitalizovaní, počet PCR a antigénnych testov, pozitivita testov, počet očkovaných prvou a druhou dávkou. V prípade indikátorov o počte nakazených, vyliečených, úmrtiach bol typ hodnoty nastavený na štatistiku, ktorá bola nastavená na súčet atribútov pre daný deň. V ostatných indikátoroch bol typ hodnoty nastavený na prvok s pol'om hodnôt, ktorý vyjadruje. V d'alších možnostiach bol doladený celkový vzhl'ad indikátorov od popisu po ikony.

Typ prvku sériový graf bol využitý na zobrazenie historických dát potvrdených prípadov, vyliečených a úmrtí. Celkom teda dashboard obsahuje 3 sériové grafy. Za pole kategórie bol zvolený dátum ako zoskupené hodnoty za jeden deň. Štatistika bola nastavená na súčet atribútov potvrdených prípadov resp. vyliečených resp. úmrtí za daný deň. V d’alších záložkách konfigurácie bol definovaný názov, farebné zobrazenie grafu a zapnutá možnost' posuvníka času (nachádza sa v hornej časti grafov). 
Koláčovým grafom je zobrazené, na kol'ko percent je dosiahnutá kolektívna imunita. . Kolektívna imunita znamená, že je naočkovaný dostatok populácie na to, aby mohol byt' vírus eliminovaný. K dosiahnutiu tejto kolektívnej imunity je potrebné naočkovanie $67 \%$ populácie. Plný kruh grafu zobrazuje práve tých $67 \%$ populácie. Typ hodnoty dát bol zvolený prvok s pol’om hodnôt atribútu kumulatívneho počtu l'udí $\mathrm{s}$ ukončeným očkovaním. Aby táto hodnota bola zobrazená v percentách bol faktor nastavený na 1 a odsadenie na 0. Minimálna hodnota bola nastavená na 0 a maximálna na 7071075 , čo predstavuje približne $67 \%$ populácie. V d’alších záložkách konfigurácie bol definovaný názov a farebné zobrazenie grafu, štýl grafu nastavený na priebeh, tvar ako kružnica a vypnutý text poslednej aktualizácie.

Prvok zoznam obsahuje dáta o vol’ných miestach v nemocniciach v jednotlivých krajoch. Je to panel, ktorý popisuje informácie o štandardných lôžkach s kyslíkom, lôžkach HFNO / CPAP, lôžkach UPV / NIV, o vol'ných prístrojoch ECMO, o vol'ných prístrojoch CVVHD, o vol’ných prenosných, operačných ventilátoroch a lôžkach na infekčnom oddelení. Pre vypisovanie informácií bola definovaná šablóna, v ktorej bolo nastavené, ako sa bude text zobrazovat'.

Do prvku bočný panel boli vložené obecné informácie o dashboarde, aké informácie v ňom môže užívatel' získat' a používanie selektorov. Tento panel je len informatívny a pri zobrazení dashboardu je zasunutý v l'avom okraji, čo bolo povolené funkciou Posunovací panel.

Posledným pridaným prvkom bolo záhlavie. V ňom bol definovaný názov dashboardu, d'alej doň boli vložené URL odkazy na stránky fakulty, stránky MZČR, COVID Portál a aktuálne správy. Tiež doň boli vložené dva selektory kategórií (vol’ba kraju a okresu pre mapové prvky a v prípade kraju aj pre zoznam) a selektoru dátumu (pre vol'bu dátumu v grafoch s historickými dátami a v mapovom prvku PES).

$\mathrm{S}$ pridaním selektorov súviselo aj nastavenie akcií. Muselo byt' definované prepojenie medzi selektorom a daným prvkom. V prípade selektoru kraju a okresu bol týmto prepojovacím atribútom názov kraju resp. okresu. V základnom nastavení nie je kraj ani okres definovaný. Pre selektor dátumu bolo zvolené, čo výber dátumu spôsobí. Akcia Filtr je nastavená pre historické dáta PES a sériové grafy s historickými dátami o potvrdených prípadoch, vyliečených a úmrtiach a tiež indikátory pre potvrdené prípady, vyliečených a úmrtiach pre vybraný deň.

Posledným krokom bolo usporiadanie všetkých prvkov. Všetky štyri prvky mapy boli funkciou Přetáhnout položku poskladané na seba, čím sa v ich spodnej časti vytvoril panel pre výber konkrétnej mapy. Týmto spôsobom boli upravené aj tri sériové grafy. Ostatné prvky (indikátory, koláčový graf a zoznam) boli rozmiestnené tak, aby boli informácie poukazujúce na podobný atribút radené pri sebe (informácie o očkovaní pri sebe, informácie o testovaní pri sebe, informácie o aktuálnej situácií v ČR pri sebe a informácie o kapacite lôžok a hospitalizovaných pacientoch pri sebe).

\section{Aktualizácia dashboardu}

S aktualizáciou aplikácie prišlo niekol'ko noviniek. Vrstvy, ktoré sú v portáli ArcGIS Online nastavené ako hostované, je možné povolit' ku st’ahovaniu. Táto funkcionalita bola v aktualizovanom dashboarde nastavená pre sériový graf s historickými dátami a prehl'adu kapacity nemocníc v krajoch.

Ďalej možno v mapovom prvku povolit' zobrazovanie bookmarkov. Ten je nastavený na počiatočnú polohu mapy.

Do selektorov je po novom možné vložit’ ikony. Tie boli všetkým selektorom pridané.

V súvislosti so zmenami v dátových sadách boli upravené skripty, aby opät fungovali správne. Do dátovej sady COVID-19: Přehled vykázaných očkování podle krajů ČR bol Ministerstvom zdravotníctva pridaný stĺpec s identifikátorom, ktorý musel byt’ odstránený, pretože v pôvodnom skripte bol identifikátor generovaný iným spôsobom. Dátová sada COVID-19: Protiepidemický systém ČR (PES) nie je od 17. 10. 2021 aktualizovaná, a preto boli informácie o systéme PES z dashboardu odstránené. Dátová sada COVID-19: Online dispečink intenzivní péče - volné kapacity podle zdravotnických zařízení (duben 2021) nie je od 20. 10. 2021 aktualizovaná a bola nahradená dátovou sadou COVID-19: Online dispečink intenzivní péče - volné kapacity podle zdravotnických zařízení (ř́jen 2021). V dátových sadách COVID-19: Základní přehled a Online dispečink intenzivní péče - volné kapacity podle zdravotnických zařízení pribudlo alebo bolo odstránených niekol'ko stĺpcov a o tieto zmeny museli byt' príslušné skripty upravené. S touto úpravou súvisela aj publikácia nových vrstiev do portálu ArcGIS Online.

Okrem dátovej časti bola upravená aj grafická stránka dashboardu, hlavne prvky mapy. 


\section{VÝSLEDKY}

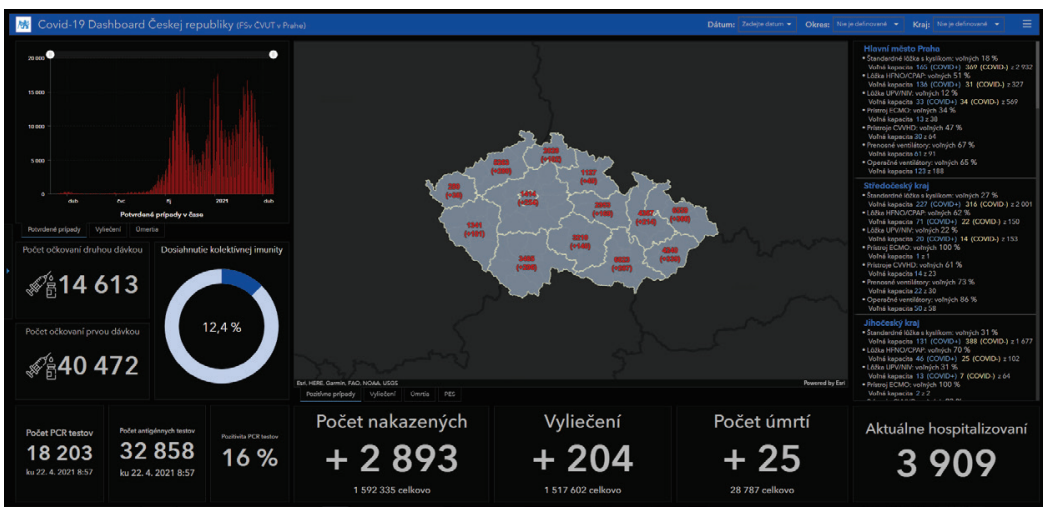

Obr. 1 Covid-19 Dashboard Českej republiky - úvodné zobrazenie.

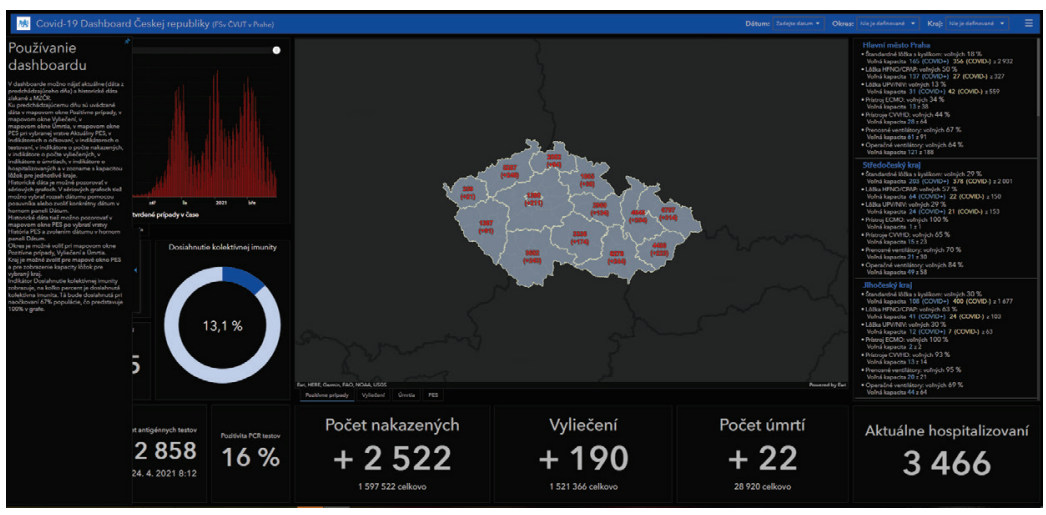

Obr. 2 Covid-19 Dashboard Českej republiky - zobrazenie bočného panelu.

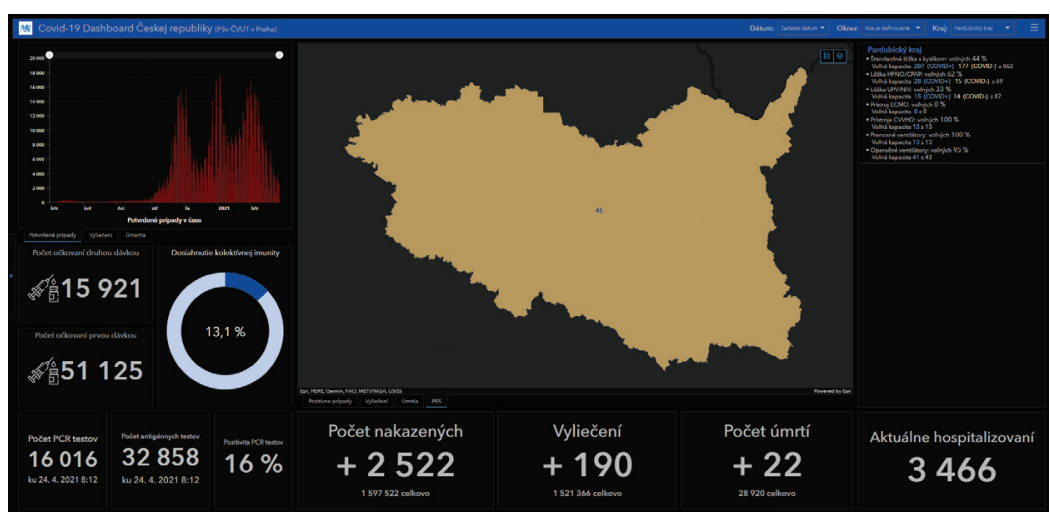

Obr. 3 Covid-19 Dashboard Českej republiky - výber kraja selektorom kategórií. 


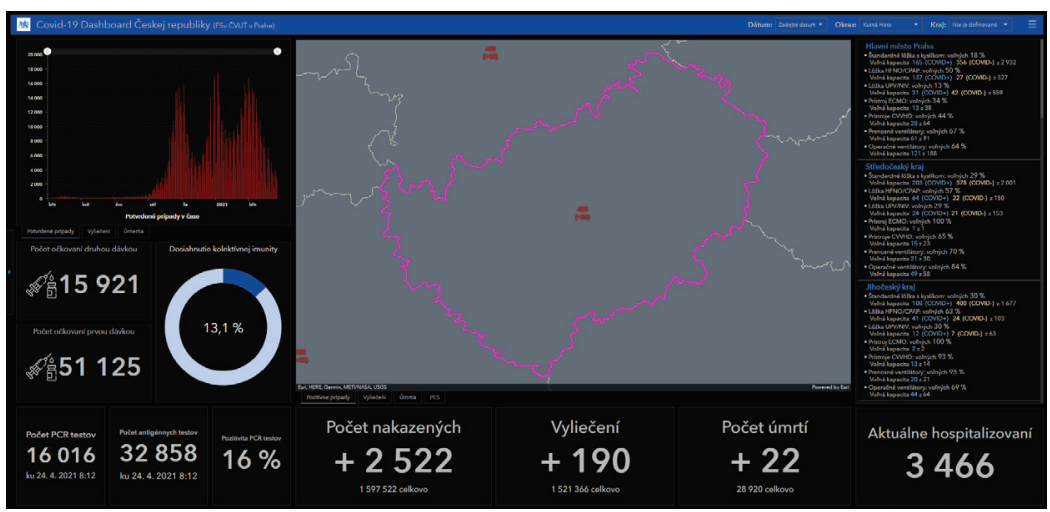

Obr. 4 Covid-19 Dashboard Českej republiky - výber okresu selektorom kategórií.

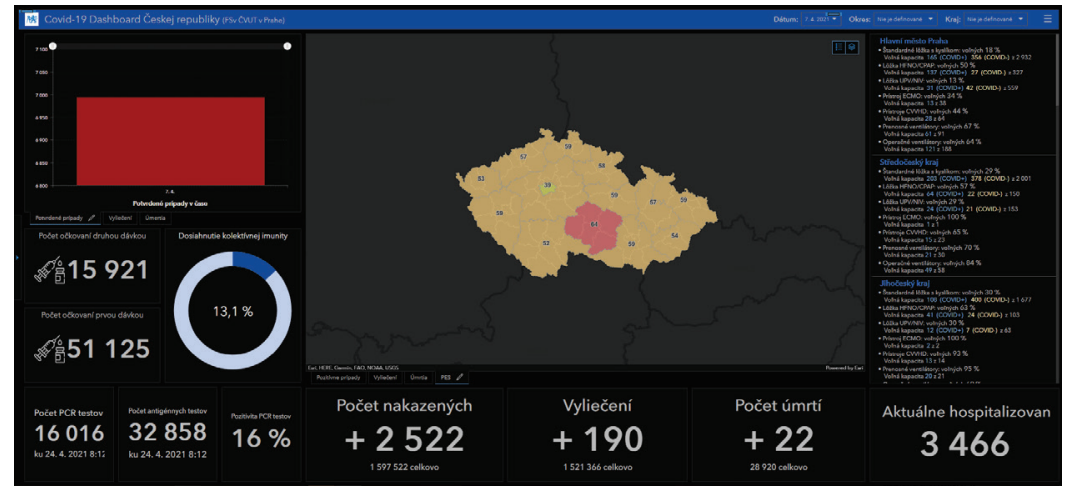

Obr. 5 Covid-19 Dashboard Českej republiky - vol'ba dátumu v selektore dátumu.

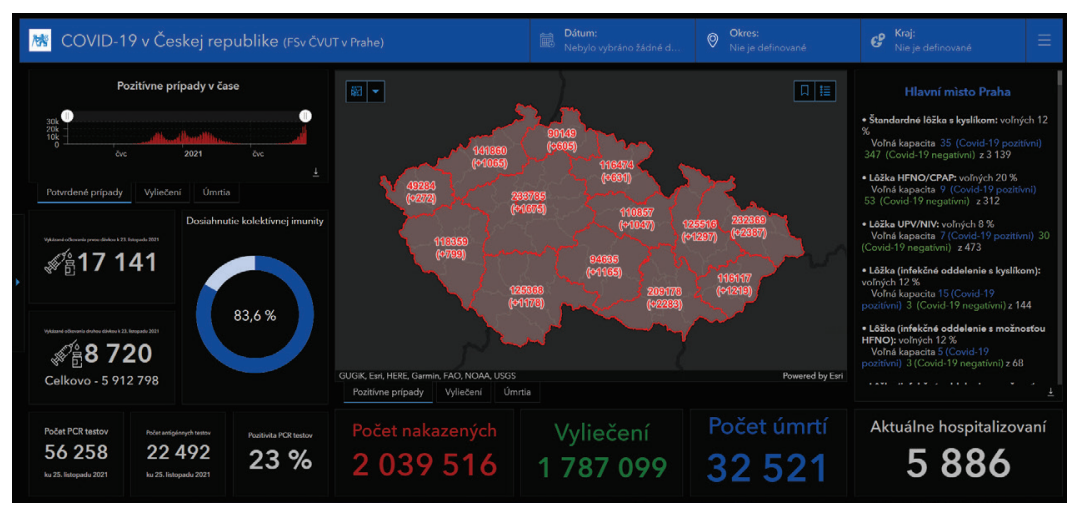

Obr. 6 Covid-19 Dashboard Českej republiky - aktualizovaný dashboard.

\section{DISKUSIA}

Ciel'om bolo naštudovat' si a aplikovat' aplikáciu ArcGIS Dashboards, popísat' jej funkcionalitu a načítanie statických a dynamických dát. Všetky tieto požiadavky boli splnené. Podarilo sa vytvorit’ funkčnú aplikáciu, ktorá sa denne aktualizuje (po aktualizácií). 
Aplikácia bola funkčná do doby, kým MZČR nezmenilo svoje poskytované dáta. Na základe toho museli byt' skripty prepísané a nahradené niektoré vrstvy v portáli ArcGIS Online využívané v dashboarde.

Skripty by bolo však vhodné ešte upravit'. Namiesto terajších skriptov napísat' jeden, ktorý by aktualizoval všetky vrstvy naraz. Tiež tento skript napísat' formou objektovo orientovaného programovania, aby bol výpočet a aktualizácia rýchlejšia. Tiež by bolo vhodné, aby tento skript nebežal len v mojom počítači.

V porovnaní so Slovenským dashboardom tento zobrazuje viac informácií a je po grafickej stránke prepracovanejší (nie v porovnaní s panelom Zahraničie, ale len panelom Slovensko).

\section{ZÁVER}

Bola podrobne naštudovaná dokumentáciu aplikácie a mnoho odborných článkov s touto problematikou a problematikou venovanou programovaniu v programovacom jazyku Python. Pre tvorbu dashboardu je lepšie čítanie odborných článkov a sledovanie videí, ako práca len za pomoci dokumentácie. Práve odborné články a videá lepšie zobrazujú a popisujú použitel'nost' tejto aplikácie.

V metodike bola popísaná tvorba dashboardu a možnosti skúmanej aplikácie. Čitatel' článku by mal byt' z dashboardu schopný vidiet' vývoj pandémie v Českej republike.

Pôvodný dashboard je dostupný na webovej adrese https://arcg.is/1ay9e4, aktualizovaný https://arcg.is/1559W8.

V závere musím povedat', že tvorba aplikácie na platforme ArcGIS Dashboards mi priniesla nové skúsenosti a poznatky nielen voblasti Esri produktov, ale aj získavaní informácií a všeobecnom prehl'ade. ArcGIS Dashboards umožňujú l'ahké pochopenie zobrazovanej problematiky aj pre tých, ktorí o nej nemajú žiadne povedomie.

\section{Použité zdroje}

[1] Covid-19 Dashboard Slovensko [online]. 2020 [cit. 2021-11-26]. Dostupné z: https://experience.arcgis.com/experience/3430195d620344c38e81d307c252c14f/page/page_0/?views =view 1

[2] COVID-19 Dashboard by the Center for Systems Science and Engineering (CSSE) at Johns Hopkins University (JHU) [online]. 2020 [cit. 2021-11-26]. Dostupné z: https://www.arcgis.com/apps/dashboards/bda7594740fd40299423467b48e9ecf6

[3] What is a dashboard [online]. [cit. 2021-11-26]. Dostupné z: https://doc.arcgis.com/en/dashboards/getstarted/what-is-a-dashboard.htm

[4] [online]. [cit. 2021-11-26]. Dostupné z: https://www.arcgeo.sk/dashboards-arcgis/

[5] COVID-19 v ČR: Otevřené datové sady a sady ke stažení [online]. [cit. 2021-11-26]. Dostupné z: https://onemocneni-aktualne.mzcr.cz/api/v2/covid-19

[6] ArcČRß 3.3 [online]. [cit. 2021-04-20]. Dostupné z: //www.arcdata.cz/produkty/geograficka-data/arccr500

[7] ArcGIS Vector Tile Style Editor [online]. [cit. 2021-11-26]. Dostupné z: https://developers.arcgis.com/vector-tile-style-editor/ 